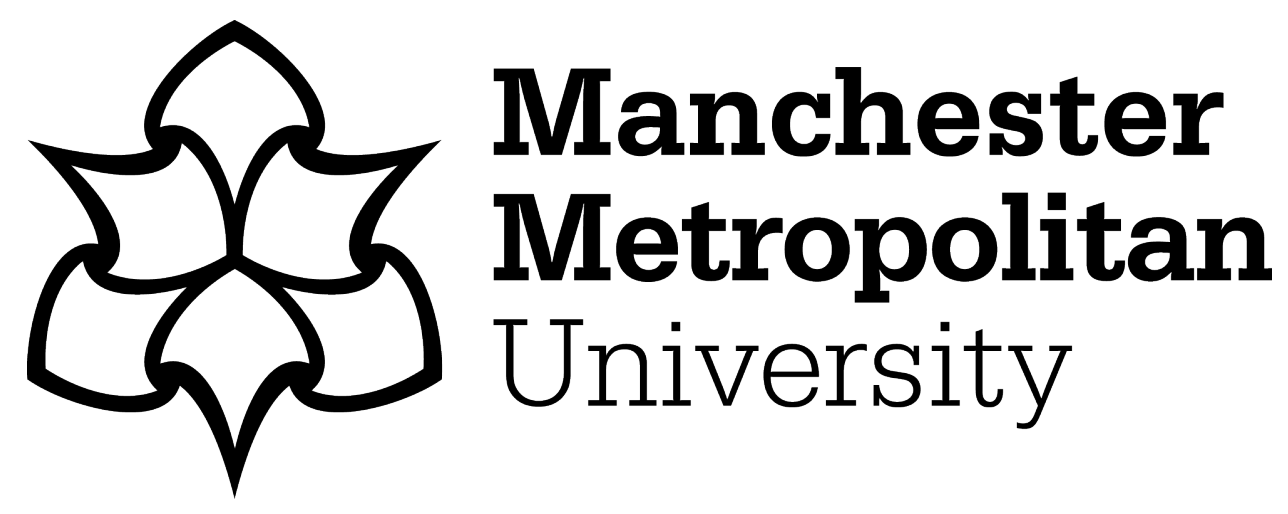

He, DS, Chen, Y, Xiang, P, Yu, ZJ and Potgieter, JH (2018) Study on the pre-treatment of oxidized zinc ore prior to flotation. International Journal of Minerals, Metallurgy and Materials, 25 (2). pp. 117-122. ISSN 1674-4799

Downloaded from: https://e-space.mmu.ac.uk/628319/

Version: Accepted Version

Publisher: Springer

DOI: https://doi.org/10.1007/s12613-018-1554-2

Please cite the published version 


\title{
Study on the pre-treatment of oxidized zinc ore prior to flotation
}

\author{
Dong-sheng He ${ }^{1)}$, Yun Chen $^{2)}$, Ping Xiang ${ }^{2)}$, Zheng-jun Yu ${ }^{2)}$, and J.H. Potgieter ${ }^{3)}$
}

1) School of Resource and Civil Engineering, Wuhan Institute of Technology, Wuhan 430205, China
2) Hunan Huaqi Resources and Environment Science \& Technology Development Co. Ltd., Zhuzhou 412005, China
3) School of Chemical and Metallurgical Engineering, University of the Witwatersrand, Johannesburg 2050, South Africa
(Received: 27 March 2017; revised: 22 June 2017; accepted: 29 June 2017)

\begin{abstract}
The pre-treatment of zinc oxide bearing ores with high slime content is important to ensure that resources are utilized optimally. This paper reports an improved process using hydrocyclone de-sliming, dispersion reagents, and magnetic removal of iron minerals for the pre-treatment of zinc oxide ore with a high slime and iron content, and the benefits compared to traditional technologies are shown. In addition, this paper investigates the damage related to fine slime and iron during zinc oxide flotation, the necessity of using hydrocyclone de-sliming together with dispersion reagents to alleviate the influence of slime, and interactions among hydrocyclone de-sliming, reagent dispersion, and magnetic iron removal. Results show that under optimized operating conditions the entire beneficiation technology results in a flotation concentrate with a $\mathrm{Zn}$ grade of $34.66 \%$ and a recovery of $73.41 \%$.
\end{abstract}

Keywords: zinc oxide ores; flotation; hydrocyclone de-sliming; magnetic deferrization

\section{Introduction}

Zinc is an important metal that ranks fourth in terms of global consumption. Metallic zinc has many uses and is frequently employed in the production of alloys, galvanization, to increase the environmental resistance of steel structures, and as a chemical additive in rubber and paints [1].

Zinc is primarily harvested as a sulfide mineral source, and separating sulfide minerals from gangue is a simple procedure conducted using conventional flotation techniques. However, with the depletion of sulfide ores, beneficiation of oxidized zinc ores has becoming an increasing focus of attention in recent years [2]. Three basic zinc oxide ore types are of economic value: hemimorphite, smithsonite, and willemite [3]. Use of a leaching/solvent extraction/electro-winning process is the most common method of extraction of zinc from low-grade zinc oxide deposits. The application of whole-ore-leaching is considered likely to be uneconomical, so separation of acid-consuming gangue minerals prior to leaching is essential to ensure the successful recovery of zinc from these deposits [4].
Flotation is another commonly used method for beneficiation and pre-treatment of oxidized zinc minerals, and extensive investigations have been conducted on the flotation of zinc oxide ores [5-8]. A number of methods employed for the flotation of the oxide minerals of the base metals have been reported, and the most important of these have been used over a long time period and are as follows [9]: sulfidization, using fatty acids as collectors, and using chelating agents and mixed anionic/cationic collectors. However, the selection of a suitable flotation method greatly depends on the accompanying gangues of the main zinc oxide mineral [8]. In addition, the flotation of oxidized zinc minerals is usually much more difficult than the flotation of corresponding sulfide minerals [6]. The most common flotation technique used commercially for the treatment of zinc oxide minerals is that of sulfidization with $\mathrm{Na}_{2} \mathrm{~S}$, followed by treatment with conventional cationic collectors, such as amine. Amines can be used for floating oxides, carbonates, silicates, and alkali earth metals such as barite, carnallite, and sylvite, and a mixture of amines and xanthates can be used as a collector [7]. Amine salts and organic ammonium compounds are very sensitive to the $\mathrm{pH}$ value of the medium and are

Corresponding author: Yun Chen_mail: yun.chen@hotmail.co.uk

(C) University of Science and Technology Beijing and Springer-Verlag GmbH Germany, part of Springer Nature 2018 
most active in slightly acid solutions but inactive in strongly alkaline and acid media. Therefore, the amount of sulfidizing reagent and $\mathrm{pH}$ value of the pulp needs to be carefully controlled during amine flotation.

Zinc oxide ores are relatively abundant in China, but currently only ores with a zinc content greater than $10 \%$ are considered for economic use. As a result, there is a mass of low-grade zinc oxide ore (with a zinc content of less than $10 \%$ ) that is abandoned in situ as waste residue, and is mainly rejected because of the high slime and iron oxide mineral content [10]. This not only represents a waste of resources but also has adverse effects on mine safety and causes environmental pollution.

Flotation is a conventional and economical method used for separating oxidized zinc minerals from their gangues [11-12]. However, it is difficult to conduct for ores with a high slime content because of the large number of fine particles that possess large surface areas and cause a so-called "slime coating phenomenon" $[2,13]$. It is also difficult to treat zinc oxide ores containing a high content of iron oxide minerals such as limonite or goethite, due to the competitive flotation behavior of the iron oxides during the process [10].

Oleic acid is the most suitable fatty acid used in the flotation of oxidized zinc minerals. In this system, $\mathrm{pH}$ value is the controlling parameter, because it controls the surface charge of the adsorption layer and determines flotation performance. Dissolved ions play a critical role, and characterization of the interaction between dissolved ions and minerals is indispensable to achieve successful selective oleic acid flotation [9].

Previous research has attempted to solve the problem of slimes by using different types of concentrators, such as a spiral chute, a shaking table, or a hydrocyclone [14-16]. Others have found that dispersion using different reagents such as sodium silicate, sodium hexametaphosphate, or sodium tripolyphosphate can be used to alleviate the damage caused by slimes to flotation [17-18]. However, no literature to date has reported the use of magnetic separation to remove iron oxide minerals associated with zinc oxide ore prior to flotation.

The aim of this paper, therefore, is to develop an improved processing technique used prior to flotation of zinc oxide obtained from low-grade zinc ores with a high content of slime and ferric oxide. This improved technique uses a combination of cyclone de-sliming, reagent dispersion, and removal of iron via magnetic separation, and is followed by use of a conventional oxidized zinc ore flotation process. Results show that this approach enables utilization of this particular oxidized zinc ore and that the process is technolo- gically viable and economically cost-effective.

\section{Experimental}

\subsection{Materials}

The zinc oxide ore residue sample used in this study was obtained from Yunnan Province, China. It has a chemical composition of $0.46 \mathrm{wt} \% \mathrm{~Pb}, 6.57 \mathrm{wt} \% \mathrm{Zn}$, and $19.51 \mathrm{wt} \%$ $\mathrm{Fe}_{2} \mathrm{O}_{3}$. A phase analysis of the zinc minerals is listed in Table 1, showing that most of the zinc exists in the form of zinc oxides. Microscopic examination shows that the major metallic minerals are smithsonite and limonite; minor metallic minerals are hemimorphite, cerusite, galena, sphalerite, and goethite; and gangue minerals are quartz, calcite, kaolinite, chlorite, sericite, and serpentine. The sample contains a slime fraction of up to $30 \mathrm{wt} \%(<5 \mu \mathrm{m})$, and the zinc ore is associated with iron. Furthermore, a phase analysis of the sample indicates that more than $95 \%$ of the zinc minerals are oxides.

Table 1. Phase analysis of zinc minerals

\begin{tabular}{lcc}
\hline \multicolumn{1}{c}{ Mineral } & Content $/ \mathrm{wt} \%$ & Distribution rate $/ \%$ \\
\hline Smithsonite & 5.13 & 78.08 \\
Zinc silicate & 1.14 & 17.35 \\
Zinc sulfide & 0.20 & 3.05 \\
Zinc ferrite and others & 0.10 & 1.52 \\
\hline Total Zn & 6.57 & 100.00 \\
\hline
\end{tabular}

\subsection{Methods}

The zinc oxide ore residue was firstly ground in a ball mill; the distribution of particle size after grinding is shown in Table 2, which indicates that around $30.02 \%$ of the minerals are finer than $5 \mu \mathrm{m}$. The size distribution of the slurry (consisting of $72 \%-74 \mu \mathrm{m}, 30 \%-5 \mu \mathrm{m}$ ) was analyzed using a $1064 \mathrm{~L}$ laser particle size analyzer, and the slurry was then introduced to a $100 \mathrm{~mm}$ hydrocyclone for de-sliming. The resulting de-slimed zinc oxide ore was subsequently treated in a SHP-500 high intensity magnetic separator to remove iron, and the residual slurry was then fed to a flotation circuit using $\mathrm{Na}_{2} \mathrm{SiO}_{3}$ and $\left(\mathrm{NaPO}_{3}\right)_{6}$ as dispersion reagents [19] and $\mathrm{Na}_{2} \mathrm{~S}$ as the sulfidizing reagent. Finally, a modified primary octadecyl amine (named XQ201) was employed as the collector [20]. Fig. 1 is a flowsheet showing the process used to treat the ore sample.

A sample weighing $20 \mathrm{~kg}$ was ground for each de-sliming experiment. The feed, overflow, and underflow were then sampled and analyzed for the $\mathrm{Zn}$ content, and the 
size distribution was analyzed using a JL-1166 laser particle size analyzer.

To remove iron, a sample weighing approximately $2 \mathrm{~kg}$ of de-slimed ore was used in the magnetic separator for separation at 15000 Gs. The magnetic product of the rougher (crude concentrate) was continually treated using the same magnetic separator at the same magnetic field strength to improve separation. The feed, the final magnetic product, and the mixed non-magnetic product were then filtered, dried, weighed, and analyzed to determine $\mathrm{Zn}$ and iron (as $\mathrm{Fe}_{2} \mathrm{O}_{3}$ ) contents.
Table 2. Particle size distribution of zinc oxide residue after grinding

\begin{tabular}{cccc}
\hline $\begin{array}{c}\text { Particle size / } \\
\mu \mathrm{m}\end{array}$ & Production / \% & Zn grade / \% & $\begin{array}{c}\text { Zn distribution } \\
\text { rate / \% }\end{array}$ \\
\hline 74 & 27.98 & 9.56 & 40.74 \\
$74-37$ & 12.30 & 7.25 & 13.57 \\
$37-19$ & 13.50 & 7.12 & 14.63 \\
$19-5$ & 16.20 & 6.88 & 16.96 \\
-5 & 30.02 & 3.08 & 14.07 \\
\hline Total & 100.00 & 6.57 & 100.00 \\
\hline
\end{tabular}

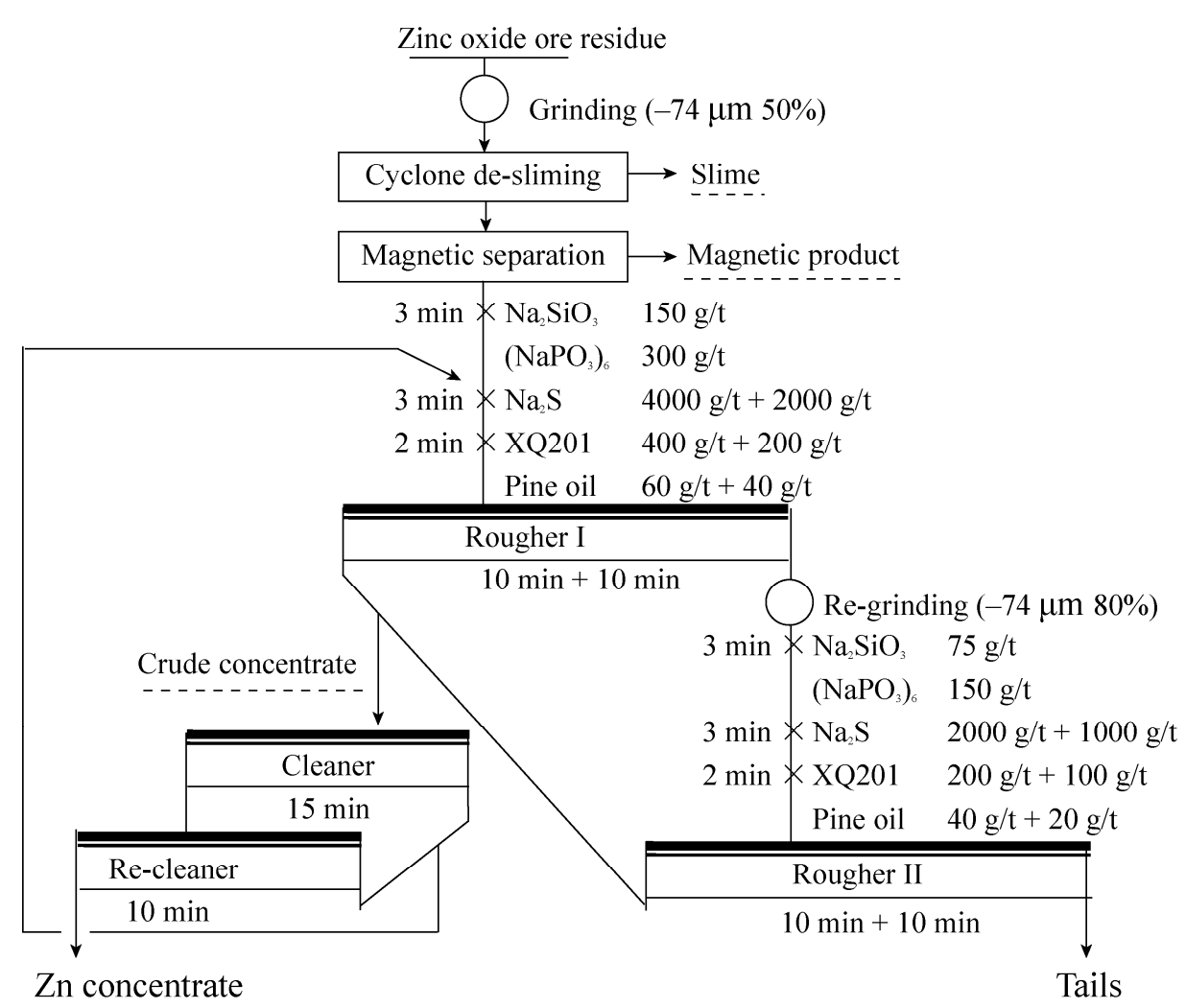

Fig. 1. Flowsheet of the beneficiation technology used to treat zinc oxide ore residue.

\section{Results and discussion}

\subsection{Effect of slime on $\mathrm{ZnO}$ flotation}

Batch flotation tests were conducted on ore samples with a variable content of $-5 \mu \mathrm{m}$ slime to evaluate the effect of slime on $\mathrm{ZnO}$ flotation (Fig. 2). The sample containing the highest content of $-5 \mu \mathrm{m}$ slime $(68.3 \%)$ was found to yield the worst separation (zinc grade of $7.60 \%$ and a recovery of $16.00 \%)$, while that with the lowest $-5 \mu \mathrm{m}(16 \%)$ content yielded the best flotation result (zinc grade of $18.20 \%$ and recovery of $70.10 \%$ ). These results indicate that slime severely hinders zinc oxide flotation and that the de-sliming step is useful for obtaining better flotation selectivity.

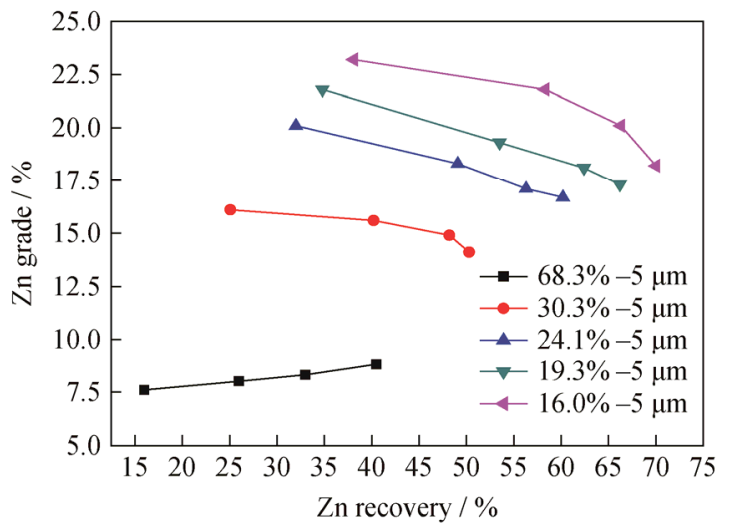

Fig. 2. Effect of slime on $\mathrm{ZnO}$ flotation $\left(\mathrm{Na}_{2} \mathrm{SiO}_{3}, 150 \mathrm{~g} / \mathrm{t}\right.$; $\left(\mathrm{NaPO}_{3}\right)_{6}, 300 \mathrm{~g} / \mathrm{t} ; \mathrm{Na}_{2} \mathrm{~S}, 6000 \mathrm{~g} / \mathrm{t}$; XQ201, $600 \mathrm{~g} / \mathrm{t}$; pine oil, $\left.100 \mathrm{~g} / \mathrm{t}\right)$. 


\subsection{Hydrocyclone de-sliming tests}

Three de-sliming tests were conducted using a hydrocyclone at a pressure of $0.2 \mathrm{MPa}$ and an unchanged overflow diameter of $20 \mathrm{~mm}$ (Table 3). Results showed an increase in the removal rate of $-5 \mu \mathrm{m}$ slime in the overflow with an increase in the yield of the overflow, while the amount of zinc lost in the overflow also increased. It was shown that although a good degree of de-sliming can be obtained using the hydrocyclone, a high removal rate of fine slime cannot be obtained together with a low loss rate of zinc in the overflow. Therefore, dispersion reagents after cyclone de-sliming are necessary and should be considered.

\subsection{Effect of dispersion on zinc oxide flotation}

To ensure that less than $8 \%$ of zinc was lost in the overflow, another batch set of flotation tests for de-slimed ore samples (containing nearly $24 \%$ of $-5 \mu \mathrm{m}$ ) was conducted in which dispersants $\left(\mathrm{Na}_{2} \mathrm{SiO}_{3}\right.$ or $\left.\left(\mathrm{NaPO}_{3}\right)_{6}\right)$ were added at dosages varying from 0 to $900 \mathrm{~g} / \mathrm{t}$ (Fig. 3). Results showed that not only was a very low zinc grade (about $14.80 \%$ ) obtained, but also a very low zinc recovery rate $(29.30 \%)$ was achieved in the absence of a dispersant. There was still more than $24 \%$ of $-5 \mu \mathrm{m}$ fine particles remaining in the underflow after de-sliming, which could be detrimental for the downstream flotation process. It was also found that increasing the dosage of dispersant led to an increase in both the zinc grade and zinc recovery, until both reached a maximum value at a dosage of approximately $450 \mathrm{~g} / \mathrm{t}$. According to Peres et al. [17], adding dispersants to the pulp causes a more negative charge on the surface of fine particles, which leads to electrostatic repulsion and reduced coagulation of fine particles; thereby jointly resulting in a restriction of the slime coating effect.

Table 3. Results of hydrocyclone de-sliming tests

\begin{tabular}{|c|c|c|c|c|c|c|c|}
\hline No. & UF diameter / mm & Product & Yield / \% & $-5 \mu \mathrm{m}$ slime $/ \%$ & Zinc assay $/ \%$ & $-5 \mu \mathrm{m}$ slime removed in $\mathrm{OF} / \%$ & Zinc lost in OF / \% \\
\hline \multirow{2}{*}{1} & \multirow{2}{*}{10} & OF & 35.15 & 56.42 & 5.46 & \multirow{2}{*}{65.65} & \multirow{2}{*}{29.19} \\
\hline & & UF & 64.85 & 16.00 & 7.18 & & \\
\hline \multirow{2}{*}{2} & \multirow{2}{*}{12} & $\mathrm{OF}$ & 20.32 & 73.48 & 5.34 & \multirow{2}{*}{49.26} & \multirow{2}{*}{16.54} \\
\hline & & UF & 79.68 & 19.30 & 6.87 & & \\
\hline \multirow{2}{*}{3} & \multirow{2}{*}{14} & OF & 9.86 & 84.95 & 5.21 & \multirow{2}{*}{27.83} & \multirow{2}{*}{7.82} \\
\hline & & UF & 90.14 & 24.10 & 6.72 & & \\
\hline
\end{tabular}

Note: OF-overflow; UF-underflow. Pressure, 0.2 MPa; OF diameter, $20 \mathrm{~mm}$.

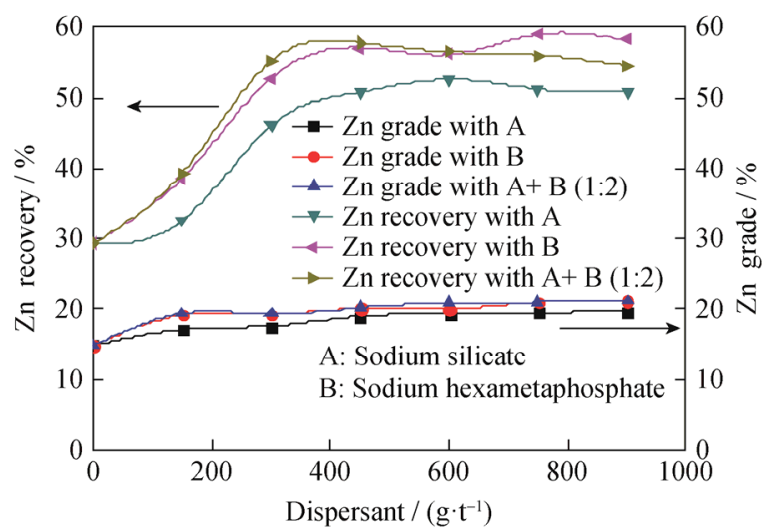

Fig. 3. Effect of dispersion on zinc oxide flotation $\left(\mathrm{Na}_{2} \mathrm{~S}, 6000 \mathrm{~g} / \mathrm{t}\right.$; XQ201, $600 \mathrm{~g} / \mathrm{t}$; pine oil, $100 \mathrm{~g} / \mathrm{t}$ ).

The dissociation of water glass (modulus 1) in water produces $\mathrm{Na}^{+}$and $\mathrm{H}_{2} \mathrm{SiO}_{4}^{2-}$. Furthermore, as a function of $\mathrm{pH}$ value, anion $\mathrm{H}_{2} \mathrm{SiO}_{4}^{2-}$ hydrolyses in two steps to $\mathrm{H}_{3} \mathrm{SiO}_{4}^{-}$and $\mathrm{H}_{4} \mathrm{SiO}_{4}$. At $\mathrm{pH}$ values below 9, the predominant specimen in the solution is silicic acid [21-22].

Sodium hexametaphosphate $\left(\mathrm{NaPO}_{3}\right)_{6}$ is a long-chain inorganic salt and a spiral chain polymer derived by polyme- rization from numerous basic structural units; it can be expressed as $\left(\mathrm{NaPO}_{3}\right)_{n}$, where $n=20-100$. Sodium hexametaphosphate has a good capacity for complexation with metal ions, including calcium ions, magnesium ions, and other metal ions, thereby generating soluble complexes. In this study, two explanations were used for the synergistic action mechanism of sodium hexametaphosphate and water glass on the flotation of zinc oxide ore. Firstly, a certain amount of metal ions are dissolved and selectively attached to the dissociation products of water glass; secondly, sodium hexametaphosphate adsorbs on the surface of zinc minerals, which not only results in a change of the $\zeta$ potential of minerals, but also changes the space steric hindrance [23-24].

\subsection{Effect of iron minerals on $\mathrm{ZnO}$ flotation}

Further batch flotation experiments (Fig. 4) were conducted to evaluate the influence of iron minerals on $\mathrm{ZnO}$ flotation. Results showed that when Fe was removed from the ore it had better flotation selectivity than ore with Fe; iron removal after cyclone de-sliming is useful for obtaining better flotation selectivity. 


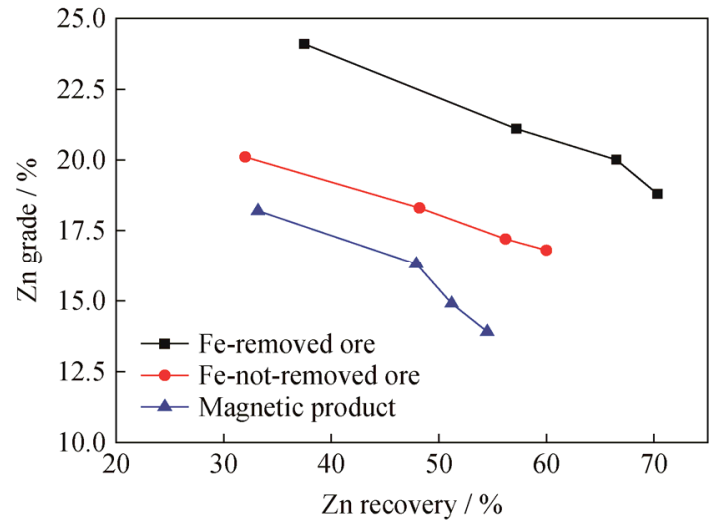

Fig. 4. Effect of iron minerals on $\mathrm{ZnO}$ flotation $\left(\mathrm{Na}_{2} \mathrm{SiO}_{3}\right.$, $150 \mathrm{~g} / \mathrm{t} ;\left(\mathrm{NaPO}_{3}\right)_{6}, 300 \mathrm{~g} / \mathrm{t} ; \mathrm{Na}_{2} \mathrm{~S}, 6000 \mathrm{~g} / \mathrm{t} ; \mathrm{XQ201}, 600 \mathrm{~g} / \mathrm{t}$; pine oil, $100 \mathrm{~g} / \mathrm{t})$.

An iron removal test (Table 4) using magnetic separation was also conducted on the de-slimed ore sample (SHP-500

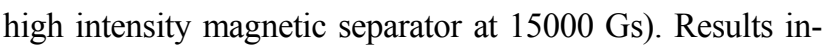
dicated that $\mathrm{Fe}$ was enriched to more than $56.00 \%$ by magnetic separation in the final magnetic product, which contained $80.08 \% \mathrm{Fe}_{2} \mathrm{O}_{3}$, and there was a simultaneous loss of zinc of $9 \%$.

Table 4. Effect of magnetic removal on zinc beneficiation

\begin{tabular}{|c|c|c|c|c|c|}
\hline \multirow{2}{*}{ Product } & \multirow{2}{*}{ Yield / \% } & \multicolumn{2}{|c|}{ Grade / \% } & \multicolumn{2}{|c|}{ Recovery / \% } \\
\hline & & $\mathrm{Zn}$ & $\mathrm{Fe}_{2} \mathrm{O}_{3}$ & $\mathrm{Zn}$ & $\mathrm{Fe}$ \\
\hline Feed & 100.00 & 6.65 & 22.30 & 100.00 & 100.00 \\
\hline $\begin{array}{c}\text { Final magnetic } \\
\text { product }\end{array}$ & 15.79 & 4.09 & 80.08 & 9.00 & 56.00 \\
\hline $\begin{array}{c}\text { Mixed } \\
\text { non-magnetic } \\
\text { products }\end{array}$ & 84.21 & 7.13 & 11.47 & 91.00 & 44.00 \\
\hline
\end{tabular}

Note: SHP-500 high intensity magnetic separator at 15000 Gs.

\subsection{Effect of re-grinding on $\mathrm{ZnO}$ flotation}

Two tests were conducted to evaluate the effect that re-grinding the tailing from the 1st flotation stage had on the results of the $2 \mathrm{nd} \mathrm{ZnO}$ flotation stage, and the grade-recovery correlation curves for each test are given in Fig. 5. For tailings without re-grinding, a concentrate containing 18.53\% $\mathrm{Zn}$ was obtained, with $37.69 \%$ of $\mathrm{Zn}$ recovered, whereas for tailings with re-grinding a concentrate containing $22.53 \%$ $\mathrm{Zn}$, with $67.27 \%$ of $\mathrm{Zn}$ recovered was obtained.

\subsection{Overall results of entire beneficiation technology}

The overall results of the entire beneficiation technology (Table 5) show that a $\mathrm{Zn}$ flotation concentrate bearing about $34.66 \% \mathrm{Zn}$ was produced, from which more than $73.41 \%$ of zinc from the Run of Mine was recovered. The magnetic product (containing $80.08 \% \mathrm{Fe}_{2} \mathrm{O}_{3}$ ) can be sent to a steel smelter as raw material, and the zinc within the magnetic product can be recovered from smelting dust using other physical or chemical methods [25-26].

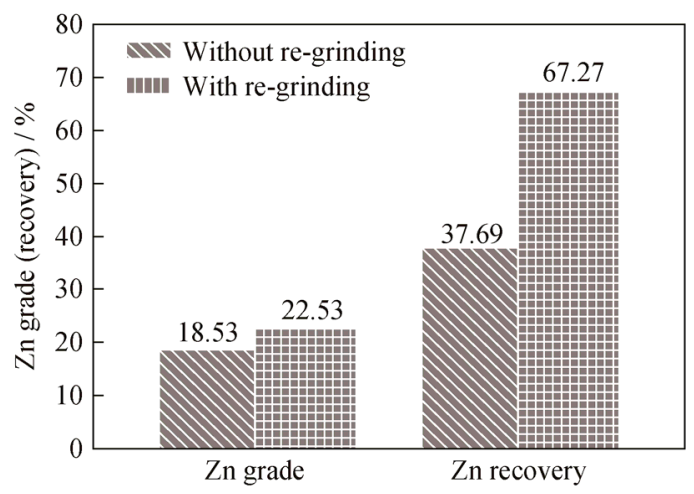

Fig. 5. Effect of re-grinding on $\mathrm{ZnO}$ flotation $\left(\mathrm{Na}_{2} \mathrm{SiO}_{3}\right.$, $150 \mathrm{~g} / \mathrm{t} ;\left(\mathrm{NaPO}_{3}\right)_{6}, 300 \mathrm{~g} / \mathrm{t} ; \mathrm{Na}_{2} \mathrm{~S}, 6000 \mathrm{~g} / \mathrm{t} ; \mathrm{XQ201}, 600 \mathrm{~g} / \mathrm{t}$; pine oil, $100 \mathrm{~g} / \mathrm{t})$.

Table 5. Results of the entire beneficiation technology

\begin{tabular}{crrrrrr}
\hline \multirow{2}{*}{ Product } & Yield $/ \%$ & \multicolumn{2}{c}{ Grade $/ \%$} & & \multicolumn{2}{c}{ Recovery $/ \%$} \\
\cline { 3 - 4 } \cline { 6 - 7 } & & $\mathrm{Zn}$ & $\mathrm{Fe}_{2} \mathrm{O}_{3}$ & & \multicolumn{1}{c}{$\mathrm{Zn}$} & $\mathrm{Fe}_{2} \mathrm{O}_{3}$ \\
\hline Original ore & 100.00 & 6.58 & 22.68 & & 100.00 & 100.00 \\
$\quad$ Slime & 9.86 & 5.21 & 24.92 & & 7.80 & 10.84 \\
$\begin{array}{c}\text { Magnetic } \\
\text { product }\end{array}$ & 14.23 & 4.09 & 80.08 & 8.84 & 50.25 \\
$\begin{array}{c}\text { Flotation } \\
\text { concentrate }\end{array}$ & 13.94 & 34.66 & 7.51 & 73.41 & 4.62 \\
$\begin{array}{c}\text { Flotation } \\
\text { tailing }\end{array}$ & 62.97 & 1.04 & 12.35 & 9.95 & 34.29 \\
\hline
\end{tabular}

\section{Conclusions}

(1) A high removal rate of fine slime cannot be obtained together with a low loss rate of zinc in the overflow; therefore, reagent dispersion after cyclone de-sliming is necessary and should be considered.

(2) Iron removal after cyclone de-sliming is useful for obtaining better flotation selectivity. Magnetic separation was used to obtain a magnetic product bearing $80.08 \%$ $\mathrm{Fe}_{2} \mathrm{O}_{3}$, and the simultaneous loss of zinc was less than $10 \%$.

(3) The entire beneficiation technology results in a $\mathrm{Zn}$ flotation concentrate bearing a $\mathrm{Zn}$ content of about $34.66 \%$, with the zinc recovery from the original ore of more than $73.41 \%$.

(4) This study succeeds in developing an improved processing technique prior to flotation of zinc oxide from low-grade zinc ores with a high content of slime and ferric oxide. This approach can be applied to similar ore types globally. 


\section{Acknowledgements}

This work was financially supported by the Natural Science Foundation of Hubei Province, China (No. 2014CFB794), the Young Fund of Wuhan Institute of Technology (No. Q201405), and the Natural Science Foundation of Hunan Province for International Cooperation and Innovation (Nos. 2017JJ4035 and 2016WK2049).

\section{References}

[1] A. Mehdilo, M. Irannajad, and H. Zarei, Flotation of zinc oxide ore using cationic and cationic-anionic mixed collectors, Physicochem. Probl. Miner. Process., 49(2013), p.145

[2] A.H. Kashani and F. Rashchi, Separation of oxidized zinc minerals from tailings: Influence of flotation reagents, Miner. Eng., 21(2008), No. 12-14, p. 967.

[3] S. Bulatovic, Handbook of Flotation Reagents: Chemistry, Theory and Practice Flotation of Sulfide Ores, Elsevier Science, 2010, p. 267.

[4] J.R. de Wet and J.D. Singleton, Development of a viable process for the recovery of zinc from oxide ores, J. South Afr. Inst. Min. Metall., 108(2008), No. 5, p. 253.

[5] S.R. Rao and J.A. Finch, Base metal oxide flotation using long chain xanthates, Int. J. Miner. Process., 69(2003), No. $1-4$, p. 251.

[6] S.H. Hosseini and E. Forssberg, Physicochemical studies of smithsonite flotation using mixed anionic/cationic collector, Miner. Eng., 20(2007), No. 6, p. 621.

[7] B.A. Wills and T.J. Napier-Munn, Wills' Mineral Processing Technology: An Introduction to the Practical Aspects of Ore Treatment and Mineral Recovery, 7th ed., Butterworth-Heinemann, Oxford, 2006, p. 257.

[8] M. Irannajad, M. Ejtemaei, and M. Gharabaghi, The effect of reagents on selective flotation of smithsonite-calcite-quartz, Miner. Eng., 22(2009), No. 9-10, p. 766.

[9] M. Ejtemaei, M. Gharabaghi, and M. Irannajad, A review of zinc oxide mineral beneficiation using flotation method, $A d v$. Colloid Interface Sci., 206(2014), p. 68.

[10] E.M. Gong, G.H. Ai, and Z.W. Wei, An experimental study on the iron recovery from the refractory zinc oxide ores, China Min. Mag., 16(2007), No. 6, p. 69.

[11] M. Ejtemaei, M. Irannajad, and M. Gharabaghi, Influence of important factors on flotation of zinc oxide mineral using cationic, anionic and mixed (cationic/anionic) collectors; Miner. Eng., 24(2011), No. 13, p. 1402.
[12] G. Önal, G. Bulut, A. Gül, O. Kangal, K.T. Perek, and F. Arslan, Flotation of Aladağ oxide lead-zinc ores, Miner. Eng., 18(2005), No. 2. p. 279.

[13] C.J. Zhu, Study on the effect of slimes on flotation of zinc oxide mineral, Multipurpose Utilization Miner. Resour., 2005, No. 1, p. 7.

[14] M.H. Jiang, S.Z. Yang, and J.Y. Yang, Industrial test research of oxide lead-zinc ore in Lanping, Nonferrous Met. Miner. Process. Sec., 2007, No. 3. p. 5.

[15] X.P. Luo, Z.M. Yan, and H.Q. Chen, Comprehensive recovery of zinc oxide from Huili zinc tailings, Met. Mine, 2007, No. 8, p. 86.

[16] Y.M. Zhou, Z.Z. Yan, X.J. Tang, and Y.W. Qiu, Mineral processing technology research for recycling oxidized zinc from tailings of lead-zinc ore, Nonferrous Met. Miner. Process. Sec., 2008, No. 1, p. 11.

[17] A.E.C. Peres, A.A. Borges, and R. Galery, The effect of the dispersion degree on the floatability of an oxidized zinc ore, Miner. Eng., 7(1994), No. 11, p. 1435.

[18] C.A. Pereira and A.E.C. Peres, Reagents in calamine zinc ores flotation, Miner. Eng., 18(2005), No. 2, p. 275.

[19] M. Rey, The flotation of oxidized ores of lead copper and zinc, [In] Recent Developments in Mineral Dressing Symposium, IMM, London, 1953, p. 541.

[20] M.J.G. Salum, A.C. de Araojo, and A.E.C. Perek, The role of sodium sulphide in amine flotation of silicate zinc minerals, Miner. Eng., 5(1992), No. 3-5, p. 411.

[21] E.M. Andrade, B.L.C.M. Costa, G.A.G. Alcântara, and R.M.F. Lima, Flotation of manganese minerals and quartz by sodium oleate and water glass, Lat. Am. Appl. Res., 42(2012), No. 1, p. 39.

[22] R.S. Duarte, R.M.F. Lima, and V.A. Leão, Effect of inorganic and organic depressants on the cationic flotation and surface charge of rhodonite-rhodochrosite, Rem: Rev. Esc. Minas, 68(2015), No. 4, p. 463.

[23] Y.P. Lu, M.Q. Zhang, Q.M. Feng, T. Long, L.M. Ou, and G.F. Zhang, Effect of sodium hexametaphosphate on separation of serpentine from pyrite, Trans. Nonferrous Met. Soc. China, 21(2011), No. 1, p. 208.

[24] M.O. Silvestre, C.A. Pereira, R. Galery, and A.E.C. Peres, Dispersion effect on a lead-zinc sulphide ore flotation, Miner. Eng., 22(2009), No. 9-10, p. 752.

[25] W.P. Zhang, Zinc recycling technology from dust and power of steel plants, Resour. Recycl., 2008, No. 3, p. 52.

[26] Z.Q. Xie, Y.F. Guo, F. Chen, and T. Jiang, Research status and prospect of comprehensive utilization of zinc-bearing dust in iron and steel plants, Sintering Pelletizing, 41(2016), No. 5, p. 53. 